\title{
Molecular epidemiological surveillance of Africa and Asia imported malaria in Wuhan, Central China: comparison of diagnostic tools during 2011-2018
}

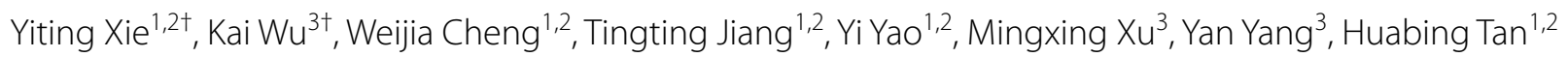
and Jian $\mathrm{Li}^{1,2^{*}}$

\begin{abstract}
Background: Malaria remains a serious public health problem globally. As the elimination of indigenous malaria continues in China, imported malaria has gradually become a major health hazard. Well-timed and accurate diagnoses could support the timely implementation of therapeutic schedules, reveal the prevalence of imported malaria and avoid transmission of the disease.

Methods: Blood samples were collected in Wuhan, China, from August 2011 to December 2018. All patients accepted microscopy and rapid diagnosis test (RDT) examinations. Subsequently, each of the positive or suspected positive cases was tested for four human-infectious Plasmodium species by using $18 \mathrm{~S}$ rRNA-based nested PCR and Taqman probe-based real-time PCR. The results of the microscopy and the two molecular diagnostic methods were analysed. Importation origins were traced by country, and the prevalence of Plasmodium species was analysed by year.
\end{abstract}

Results: A total of 296 blood samples, including 288 that were microscopy and RDT positive, 7 RDT and Plasmodium falciparum positive, and 1 suspected case, were collected and reanalysed. After application of the two molecular methods and sequencing, 291 cases including 245 P. falciparum, 15 Plasmodium vivax, 20 Plasmodium ovale, 6 Plasmodium malariae and 5 mixed infections ( 3 P. falciparum + P. ovale, 2 P. vivax + P. ovale) were confirmed. These patients had returned from Africa (95.53\%) and Asia (4.47\%). Although the prevalence displayed a small-scale fluctuation, the overall trend of the imported cases increased yearly.

Conclusions: These results emphasize the necessity of combined utilization of the four tools for malaria diagnosis in clinic and in field surveys of potential risk regions worldwide including Wuhan.

Keywords: Imported malaria, Microscopic examination, Molecular diagnosis, Rapid diagnosis test, Nested PCR, Realtime PCR

\footnotetext{
*Correspondence: yxlijian@163.com

†Yiting Xie and Kai Wu contributed equally

1 Department of Human Parasitology, School of Basic Medical Sciences, Hubei University of Medicine, Shiyan 442000, People's Republic of China

Full list of author information is available at the end of the article
}

\section{Background}

Malaria remains a serious threat to public health around the world, with an estimated 228 million cases and 405,000 deaths in 2018 worldwide [1]. The main epidemic areas of malaria are distributed in Africa (93\%), followed by Southeast Asia (SE Asia) (3.4\%) and the

c) The Author(s) 2020. This article is licensed under a Creative Commons Attribution 4.0 International License, which permits use, sharing, adaptation, distribution and reproduction in any medium or format, as long as you give appropriate credit to the original author(s) and the source, provide a link to the Creative Commons licence, and indicate if changes were made. The images or other third party material in this article are included in the article's Creative Commons licence, unless indicated otherwise in a credit line to the material. If material is not included in the article's Creative Commons licence and your intended use is not permitted by statutory regulation or exceeds the permitted use, you will need to obtain permission directly from the copyright holder. To view a copy of this licence, visit http://creativeco mmons.org/licenses/by/4.0/. The Creative Commons Public Domain Dedication waiver (http://creativecommons.org/publicdomain/ zero/1.0/) applies to the data made available in this article, unless otherwise stated in a credit line to the data. 
Eastern Mediterranean Region (2.1\%) [1]. The World Health Organization (WHO) hopes to eliminate malaria in at least 35 additional countries (based on data from 2015 ) by 2030 [2]. To assist in this goal, China planned to eliminate the disease by 2020 [3]. In China, the occurrence and burden of indigenous malaria have rapidly decreased due to an integrated malaria control and elimination strategy implemented in 2000 [4]. It is worth noting that as of 2017, no cases of indigenous malaria have been reported in the entire country. In accordance with the nationwide status, the control of indigenous malaria in the Hubei Province of China was successful, and zero indigenous malaria cases have been reported in Hubei since 2013 [5]. However, imported malaria has gradually become a major threat in need of a process of prevention, control and elimination in endemic and nonendemic areas globally, including in China. Furthermore, it is worth mentioning that imported malaria cases from Africa and SE Asia have been gradually increasing yearly in China, including in the provincial capital of the Hubei province, Wuhan $[4,5]$. For efficient control and in order to achieve malaria eradication before 2020 in China according to the state plan [3], imported malaria patients in China, especially in first-tier cities with a high population density and mobility, such as Wuhan, need to be quickly noticed.

There are five primary Plasmodium species causing malaria in humans, including Plasmodium falciparum, Plasmodium vivax, Plasmodium ovale, Plasmodium malariae, and Plasmodium knowlesi. Different Plasmodium species infections can cause dissimilar disease characteristics. Amongst them, P. falciparum is responsible for most of the morbidity and mortality of humans in sub-Saharan Africa, and other malarious tropical areas around the world $[6,7]$. Populations such as young children, older adults, immunosuppressed patients and travellers from malaria-free zones to epidemic areas are particularly susceptible to falciparum malaria. Plasmodium falciparum can also increase the risk of severe malaria and adverse complications in pregnant women, such as maternal death, miscarriage, stillbirth and neonatal death. If patients fail to get diagnosis and treated within $24 \mathrm{~h}$ after the onset of falciparum malaria, it may be fatal [8]. Plasmodium vivax is generally the culprit for the majority of malaria cases in areas with tropical and temperate climates and is considered to be a neglected tropical disease $[9,10]$. Severe $P$. vivax malaria cases have been reported in endemic areas of (sub) tropical countries. For $P$. vivax, a dormant form named hypnozoite, could stay in the liver and may lead to the malaria relapses several months or even years later [8]. Plasmodium ovale is mainly prevalent in Africa and Asia, particularly in West Africa [7]. Plasmodium ovale seldom leads to severe malaria among people in endemic regions, but can cause severe malaria disease in naive visitors $[11,12]$. It is comprised of two subspecies, $P$. ovale curtisi and P. ovale wallikeri [13]. Plasmodium ovale curtisi has a significantly longer latency duration than $P$. o. wallikeri $[14,15]$. Like $P$. vivax, $P$. ovale can also form hypnozoites in the host liver, which makes the prevention and treatment of both vivax and ovale malaria more difficult [8]. Plasmodium malariae cases have been reported worldwide and are particularly prevalent in West Africa. Plasmodium malariae usually causes the mildest infections and very rarely has life-threatening results. However, it may cause splenomegaly or renal damage during chronic infection [7]. Plasmodium knowlesi was initially found in SE Asia in wild macaques, but it can also infect humans [16]. Although human-mosquito-human transmission has not been reported for this malaria species, it is a health threat to people in forested areas of SE Asia because it may cause organ failure or even fatal outcomes $[8,17,18]$. Beyond that, simultaneous infections with more than one human Plasmodium species commonly happen, especially in endemic regions [19]. However, the influence of malaria caused by $P$. vivax, $P$. ovale and $P$. malariae as well as mixed infections is frequently underestimated [12, 15, 20-22]. Most importantly, different Plasmodium infections should be treated with the corresponding chemoprophylaxis and appropriate treatment principles [8]. Therefore, for timely and efficient treatment and to prevent malaria transmission, early and accurate diagnosis of Plasmodium species infection is meaningful.

As it is inexpensive and has a relatively high sensitivity for species recognition and even parasite density quantification, microscopic examination of thick and thin blood smear is traditionally regarded as the gold standard for malaria detection [23, 24]. However, the use of microscopic examination has been restricted because it requires well-trained laboratory personnel and shows less sensitive for low parasitaemia levels [25-27]. Besides, different observers may have two to three-fold discrepancies in parasite quantification [28]. More importantly, mixed infections of different Plasmodium species are frequently missed [29]. The two subspecies of $P$. ovale ( $P$. o. curtisi and $P$. o. wallikeri) cannot be distinguished by microscopy. Misidentification may also happen between different species [30]. All of the above may induce the unreasonable usage of anti-malarial drugs, hamper parasite clearance and lead to the transmission of malaria, and even anti-malarial drug resistance. The rapid diagnosis test (RDT) as an immunologic method usually targets Plasmodium-specific antigens in blood samples such as histidine-rich protein 2 (HRP2) and lactate dehydrogenase (LDH) [7]. RDT offers a rapid diagnosis and 
can be conducted by users without extensive training. It often has comparable sensitivity to microscopy. However, RDT can only distinguish falciparum and non-falciparum Plasmodium species infection [31]. Furthermore, false negative results by RDT were also reported in previous studies [32-34]. Therefore, molecular tools such as nested PCR and real-time PCR that could not only detect Plasmodium infection, but also allow for accurate species identification by primer design should be used. Nested PCR with two rounds of amplification can improve the detection sensitivity. Sequencing of products from nested PCR represents a further reliable guarantee for species identification $[35,36]$. The major advantages of real-time PCR include direct result reading without the need for downstream analysis or quantification of the DNA copy number [37, 38].

Using suitable and effective methods to timely identify imported malaria is essential for successfully completing the target assessment task for malaria elimination in China, Africa and SE Asia. Therefore, the present study aimed to confirm the Plasmodium species involved in all imported malaria cases in Wuhan by using microscopy, RDT, nested PCR and real-time PCR. The performances of these methods in malaria diagnosis were assessed to supply more reference values for their future use. Analysis of their diagnostic results revealed the prevalence and characteristics of imported malaria in Wuhan, China.

\section{Methods}

\section{Collection of study specimens}

Blood samples from clinically suspected patients with symptoms of malaria were cumulatively collected from the Center for Disease Prevention and Control (CDC) of Wuhan, China, from August 2011 to December 2018. Approximately 2 to $5 \mathrm{ml}$ blood was drawn from each patient for microscopy and RDT testing and $400 \mu \mathrm{l}$ of each sample was stored on $3 \mathrm{MM}$ Whatman filter paper for molecular verification. Ethical approval for this study was obtained from the Medical Ethics Committee of the Hubei University of Medicine and Wuhan $\mathrm{CDC}$. Informed consent was provided by all participating individuals.

\section{Microscopic examination and RDT assays}

The blood samples were first subjected to One Step Malaria HRP2/pLDH (P.f/Pan) (Wondfo, Guangzhou, China) detection. Subsequently, thick and thin peripheral blood smears were made by the standard method [39]. Giemsa staining and microscopic examinations were conducted by professionals in the Wuhan CDC. Parasitaemia (parasites/ $\mu$ l) was determined according to the previous report [40]. No asexual form of Plasmodium detected in 200 high-power fields in the thin blood films and no parasites for every 1000 white blood cells were considered as negative [39, 41].

\section{Genomic DNA extraction}

Genomic DNA (gDNA) from the microscopic-positive or suspected positive blood samples was extracted using a TIANamp blood DNA kit (Tiangen Biotech Co., Ltd., Beijing, China). Briefly, $6 \mathrm{~mm} \times 6 \mathrm{~mm}$ blood spot (approximately $130 \mu \mathrm{l}$ peripheral blood) was treated following the manufacturer's instruction and finally dissolved in $50 \mu \mathrm{l}$ elution buffer. After quantification with Gene 5, the purified gDNA was packed as aliquots and stored at $-20^{\circ} \mathrm{C}$ until further use.

\section{Taqman probe based Real-time PCR}

Probes were designed for the parasite species, including P. falciparum, $P$. vivax, $P$. ovale (P. o. curtisi, $P$. o. wallikeri) and $P$. malariae, so they could be distinguished with real-time PCR. The preparation of primers and Taqman probes was according to previous documents [35, 42] (the primers are listed in Table 1). Reactions were performed using the Premix EX Taq ${ }^{\mathrm{TM}}$ probe qPCR (Takara, Japan) following the manufacturer's instructions. Briefly, a reaction mixture consisted of $12.5 \mu \mathrm{l}$ premix Ex Taq $(2 \times), 0.5 \mu \mathrm{l}$ of each primer (final $0.2 \mu \mathrm{M}$ ), and approximately $1 \mu \mathrm{l}$ fluorescence probe (final $0.1-0.5 \mu \mathrm{M}$ ), and $2 \mu \mathrm{l}$ DNA template in a final total volume of $25 \mu \mathrm{l}$ supplemented with ultrapure water. All reactions were performed as suggested by the manufacturer, including 1 cycle of $95^{\circ} \mathrm{C}$ for $30 \mathrm{~s}, 40$ repeated cycles of $95^{\circ} \mathrm{C}$ for $5 \mathrm{~s}$ and $60{ }^{\circ} \mathrm{C}$ for $30 \mathrm{~s}$, on a CFX96 real-time PCR machine (Bio-Rad, USA).

\section{Nested PCR assay}

The above samples were further subjected to nested PCR. For nested PCR, the classical primers targeting the Plasmodium 18S small subunit ribosomal RNA (18S ssrRNA) gene were synthesized and used as previously described [43, 44] (the primers are listed in Table 1). The reaction system for the primary round contained $12.5 \mu \mathrm{l}$ $2 \times$ NovoStar Green PCR Mix $(400 \mu \mathrm{M}$ deoxynucleoside triphosphate [dNTP], $50 \mathrm{U} / \mathrm{ml}$ NovoStar Taq DNA polymerase, $4 \mathrm{mM} \mathrm{Mg}^{2+}$ and $2 \times$ PCR buffer), $1 \mu \mathrm{l}$ of each primer (rPLU1 and rPLU5 for 18S Plasmodium species, $10 \mu \mathrm{M}$ ) and $1 \mu \mathrm{l}$ DNA template in a final total volume of $25 \mu \mathrm{l}$ supplemented with ultrapure water. The amplification was carried out using the following conditions: initial denaturation at $95^{\circ} \mathrm{C}$ for $3 \mathrm{~min}, 30$ repeated cycles at $95{ }^{\circ} \mathrm{C}$ for $30 \mathrm{~s}, 55^{\circ} \mathrm{C}$ for $1 \mathrm{~min}, 72{ }^{\circ} \mathrm{C}$ for $1 \mathrm{~min}$, followed by a final extension at $72{ }^{\circ} \mathrm{C}$ for $5 \mathrm{~min}$. A $1670 \mathrm{bp}$ PCR product was obtained from each sample after the primary amplification, which was then used as the DNA template for the secondary amplification. The reaction 
Table 1 Primers and probes for Plasmodium species detection

\begin{tabular}{|c|c|c|c|c|c|}
\hline Method & Species & Primer & Sequence $\left(5^{\prime}-3^{\prime}\right)$ & Length (bp) & References \\
\hline \multirow{14}{*}{ Nested PCR } & \multirow[t]{2}{*}{ Plasmodium sp. } & rPLU1 & TCAAAGATTAAGCCATGCAAGTGA & \multirow[t]{2}{*}{1670} & \multirow[t]{10}{*}{ [43] } \\
\hline & & rPLU5 & CCTGTTGTTGCCTTAAACTTC & & \\
\hline & \multirow[t]{2}{*}{ P. falciparum } & rFAL1 & TTAAACTGGTTTGGGAAAACCAAATATATT & \multirow[t]{2}{*}{205} & \\
\hline & & rFAL2 & ACACAATGAACTCAATCATGACTACCCGTC & & \\
\hline & \multirow[t]{2}{*}{ P. vivax } & rPVIV1 & CGCTTCTAGCTTAATCCACATAACTGATAC & \multirow[t]{2}{*}{121} & \\
\hline & & rPVIV2 & ACTTCCAAGCCGAAGCAAAGAAAGTCCTTA & & \\
\hline & \multirow[t]{2}{*}{ P. malariae } & rMAL1 & ATAACATAGTTGTACGTTAAGAATAACCGC & \multirow[t]{2}{*}{145} & \\
\hline & & rMAL2 & AAAATTCCCATGCATAAAAAATTATACAAA & & \\
\hline & \multirow[t]{2}{*}{ P. ovale } & rOVA1WC & TGTAGTATTCAAACGCAGT & \multirow[t]{2}{*}{$659-662$} & \\
\hline & & rOVA2WC & TATGTACTTGTTAAGCCTTT & & \\
\hline & \multirow[t]{2}{*}{ P. ovale curtisi } & rOVA1 & ATCTCTTTTGGCTATTTTTTAGTATTGGAGA & \multirow[t]{2}{*}{800} & \multirow[t]{4}{*}{ [44] } \\
\hline & & rOVA2 & GGAAAAGGACACATTAATTGTATCCTAGTG & & \\
\hline & \multirow[t]{2}{*}{ P. ovale wallikeri } & rOVA1V & ATCTCCTTTACTTTTTGTACTGGAGA & \multirow[t]{2}{*}{780} & \\
\hline & & rOVA2V & GGAAAAGGACACTATAATGTATCCTAATA & & \\
\hline \multirow[t]{10}{*}{ Real-time PCR } & \multirow[t]{2}{*}{ Plasmodium sp. } & Plasmo 1 & GTTAAGGGAGTGAAGACGATCAGA & & \multirow[t]{6}{*}{ [35] } \\
\hline & & Plasmo 2 & AACCCAAAGACTTTGATTTCTCATAA & & \\
\hline & P. falciparum & P. fal-probe & FAM-AGCAATCTAAAAGTCACCTCGAAAGATGACT-TAMRA & & \\
\hline & P. vivax & P. v-probe & HEX-AGCAATCTAAGAATAAACTCCGAAGAGAAAATTCT-TAMRA & & \\
\hline & P. malariae & P. m-probe & FAM-CTATCTAAAAGAAACACTCAT-MGB & & \\
\hline & P.ovale & P. o-probe & HEX-CGAAAGGAATTTTCTTATT-MGB & & \\
\hline & \multirow[t]{2}{*}{ P. ovale } & POF & ATAAACTATGCCGACTAGGTT & & \multirow[t]{4}{*}{ [42] } \\
\hline & & POR & ACTTTGATTTCTCATAAGGTACT & & \\
\hline & P. ovale curtisi & POC-probe & FAM-TTCCTTTCGGGGAAATTTCTTAGA-BHQ1 & & \\
\hline & P. ovale wallikeri & POW-probe & HEX-AATTCCTTTTGGAAATTTCTTAGATTG-BHQ1 & & \\
\hline
\end{tabular}

system and conditions in the second round were similar to the first round with minor modifications. Briefly, the annealing temperature was adjusted to $56{ }^{\circ} \mathrm{C}$, and the extension time was changed to $30 \mathrm{~s}$, considering the amplification products were shorter in the second reaction. All the products from the secondary amplification were subjected to $1 \%$ agarose gel electrophoresis and judged by their band sizes. Products of the nested PCR were used for sequencing if divergent results occurred among the microscopy and the two molecular methods.

\section{Data analysis}

To calculate the diagnostic sensitivity, specificity, positive predictive value (PPV), negative predictive value (NPV), disease prevalence (DP) and accuracy of four Plasmodium species, results from nested PCR were considered as the standard. Accuracy was calculated with MedCalc-Diagnostic test evaluation. The remaining five parameters mentioned above and their 95\% confidence interval $(95 \% \mathrm{CI})$ were obtained from online calculator named vassarstats [45]. Briefly, the case number shown positive by both nested PCR and microscopy/ real-time PCR was defined as True Positive (a); the case number shown positive by nested PCR but negative by microscopy/real-time PCR was defined as False Negative (b); the case number shown positive by microscopy/ real-time PCR but negative by nested PCR was defined as False Positive (c); The case number shown negative by both nested PCR and microscopy/real-time PCR was defined as True Negative (d). Sensitivity $=a /(a+b)$; Specificity $=d / \quad(c+d) ; \quad$ Prevalence $=(a+b) /$ $(\mathrm{a}+\mathrm{b}+\mathrm{c}+\mathrm{d}) ; \quad \mathrm{PPV}=($ Sensitivity $\times$ Prevalence $) /[($ Sensitivity $\times$ Prevalence $)+(1-$ Specificity $) \times(1-$ Prevalence $)$; $\mathrm{NPV}=$ Specificity $\times(1-$ Prevalence $) /[(1-$ Sensitivity) $] \times$ Prevalence + Specificity $\times(1-$ Prevalence $)]$; Accuracy $=$ Sensitivity $\times$ Prevalence + Specificity $\times(1-$ Prevalence). Flowchart and patients distribution map were drown in Microsoft Office Visio 2010. Other figures were finished in Graphpad Prism 5.0. The trend analysis was carried out by trend estimation in linear regression analysis of SPSS 22.0.

\section{Results}

\section{Microscopy and RDT detection}

A total of 296 blood samples from malaria suspected patients were collected (Fig. 1). By using microscopy and RDT, 288 positive samples including $243 P$. falciparum, 17 P. vivax, 21 P. ovale, 6 P. malariae and 1 coinfection 


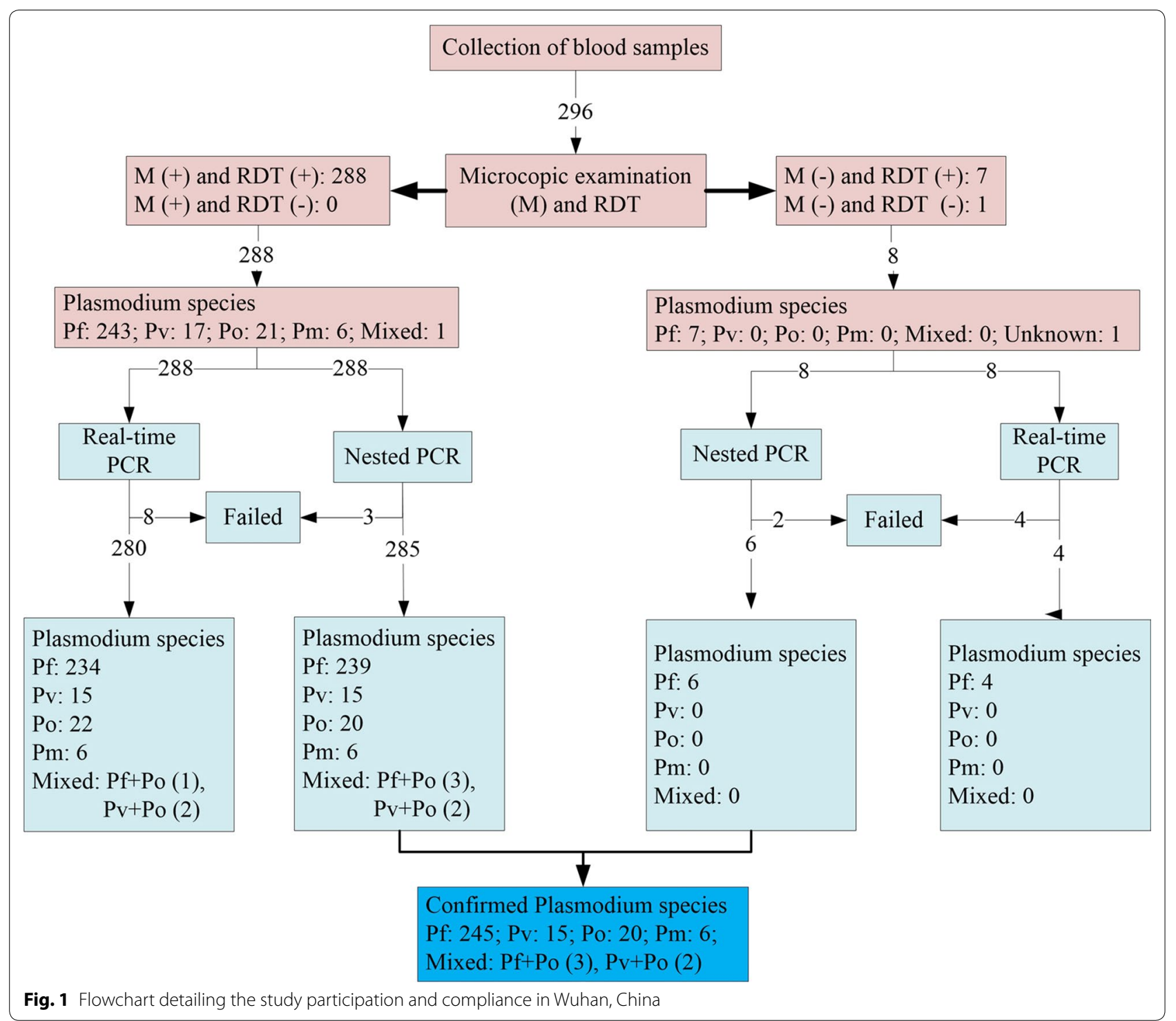

(P. falciparum $+P$. ovale) were observed. Seven out of the remaining 8 cases (296 minus 288) were microscopy negative but RDT positive (Fig. 1). The final case was both microscopy and RDT negative but was a suspected patient with clinical symptoms of malaria.

For the 243 microscopy-positive P. falciparum cases (Fig. 2a), parasitaemia ranged from 100 to 500,000 parasite $/ \mu \mathrm{l}$, and the mean parasite density was 88,879 parasite $/ \mu \mathrm{l}$ (95\% CI 71,794-105,963). These cases were divided into six groups according to their densities: Very Low $(\leq 100$ parasite/ $\mu \mathrm{l})$, Low $(101-500$ parasite $/ \mu \mathrm{l})$, Low-middle (501-3000 parasite/ $\mu \mathrm{l})$, Middle (3001-10,000 parasite/ $\mu \mathrm{l})$, Middle-high $(10,001-$ $100,000$ parasite/ $\mu \mathrm{l})$ and High $(>100,000$ parasite/ $\mu \mathrm{l})$.
From the very low group to the high group (see Fig. 2b and Table 2), case numbers of $P$. falciparum for each density interval were 7 (2.88\%), 26 (10.70\%), $34(33+1$, $13.99 \%), 30$ (12.35\%), 96 (39.51\%) and 50 (20.58\%), respectively. For $P$. vivax, parasitaemia ranged from 100 to 30,000 parasite/ $\mu$ l and the mean parasite density was 4600 parasite/ $\mu$ l (95\% CI 989-8211). For $P$. ovale, parasitaemia ranged from 500 to 10,000 parasite/ $\mu \mathrm{l}$ and the mean parasite density was 2610 parasite $/ \mu$ l (95\% CI 1348-3871). Of which, $23.53 \%$ (4/17) of $P$. vivax and $19.05 \%(4 / 21)$ of $P$. ovale had parasite densities $\leq 500$ parasite/ $\mu l$. All of the $6 P$. malariae cases had parasite densities from 800 to 4000 parasite/ $\mu \mathrm{l}$ and the one mixed infection was 50,000 parasite $/ \mu \mathrm{l}$ (see Fig. 2a). 

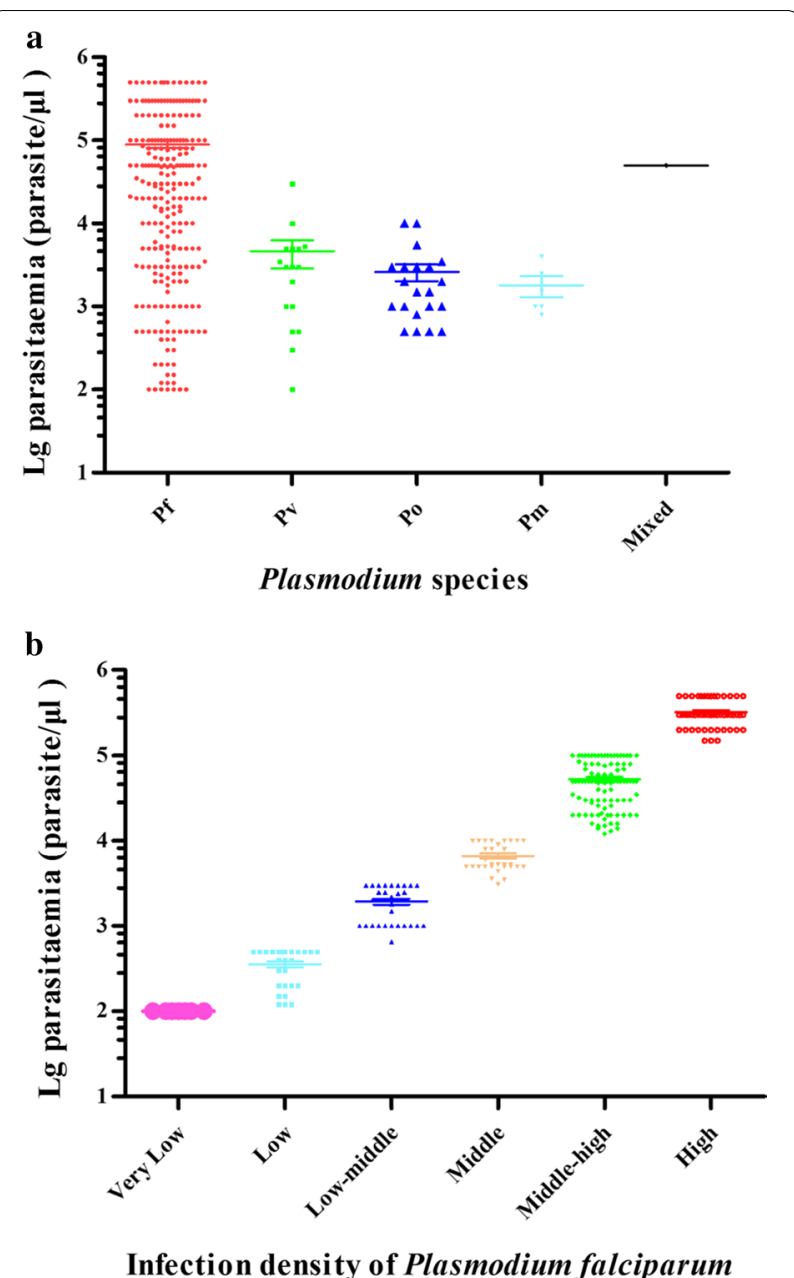

Fig. 2 Parasitaemia for Plasmodium species infection from imported malaria clinical cases in Wuhan, China. a Parasitaemia for four Plasmodium species infection. $\mathbf{b}$ Infection density of Plasmodium falciparum

\section{Confirmation of the parasite species with PCR-based methods}

These samples were confirmed via both nested PCR and real-time PCR. After reconfirmation by nested PCR (the primers are shown in Table 1), 1.04\% (3/288) microscopypositive and $25 \%(2 / 8)$ microscopy-negative cases failed to be detected. However, $2.78 \%$ (8/288) microscopy-positive and 50\% (4/8) microscopy-negative subjects were negative by real-time PCR (Fig. 1). Nested PCR products of the 7 cases (12 minus 5), which were P. falciparum positive by nested PCR, but negative by real-time PCR, were sequenced, and the results proved they were all $P$. falciparum infections. As shown in Table 2, the 5 negative cases by nested PCR were distributed either in the three groups with relatively low $P$. falciparum density (Very low, Low, Low-middle) or in the microscopy-negative group. For the 12 cases that were not detected by real-time PCR, they were all caused by P. falciparum. Their parasite density distributions were highly in accordance with those in the nested PCR detection, including 2 cases in the Very low group, 5 cases in the Low group, 1 case in the Lowmiddle group and 4 cases in the microscopy-negative group. Additionally, both molecular tools revealed one $P$. falciparum plus $P$. ovale mixed infection case among the microscopy-positive $P$. falciparum samples. The one suspected case negative by both microscopy and RDT was proven to be $P$. falciparum infection.

Of the 17 microscopy-positive $P$. vivax cases, two actually proved to be $P$. vivax plus $P$. ovale mixed infection by both nested and real-time PCR. All 21 microscopypositive $P$. ovale cases were diagnosed as positive by realtime PCR, but two of them proved to be $P$. falciparum plus $P$. ovale mixed infection by nested PCR and subsequent sequencing. The identification of the $6 P$. malariae cases showed the same results by three methods. There was also a case that was diagnosed as $P$. falciparum plus $P$. ovale infection by microscopy. However, both nested PCR and real-time PCR revealed the existence of $P$. ovale but not $P$. falciparum (Table 2). Subspecies identification of the 20 single $P$. ovale positive cases showed that they consisted of 10 P. o. curtisi, 9 P. o. wallikeri and 1 mixture of the two subspecies according to the nested PCR and sequencing. Real-time PCR revealed similar results except for 3 P. o. curtisi negative cases.

\section{Diagnostic profile of Plasmodium species by the different methods}

As shown in Fig. 1 and Table 3, amongst the 296 samples, there were 243 (82.09\%) P. falciparum, 17 (5.74\%) P. vivax, 21 (7.09\%) P. ovale, 6 (2.03\%) P. malariae, 1 $(0.34 \%)$ mixed infection (P. falciparum $+P$. ovale) and 8 (2.70\%) negative cases according to microscopic observations. Based on the nested PCR, 245 (82.77\%), 15 (5.07\%), $20(6.76 \%)$ and $6(2.03 \%)$ cases were identified as single infection by $P$. falciparum, $P$. vivax, $P$. ovale and $P$. malariae, respectively, whereas dual species mixed infections included $3(1.01 \%)$ cases of $P$. falciparum $+P$. ovale, $2(0.68 \%)$ cases of $P$. vivax $+P$. ovale and 5 (1.69\%) negative cases. Real-time PCR revealed a few minor discrepant results, including 238 (80.41\%) P. falciparum, 15 (5.07\%) P. vivax, 22 (7.43\%) P. ovale, 6 (2.03\%) P. malariae, $1(0.34 \%)$ mixed infections of P. falciparum $+P$. ovale, $2(0.68 \%)$ cases of $P$. vivax $+P$. ovale and 12 (4.05\%) negative cases. No triple or quadruple infection were detected in these samples.

\section{Diagnostic performance of microscopy and real-time PCR compared to nested PCR}

Nested PCR was appointed as a reference for the diagnostic summarizing of the Plasmodium species as well 
Table 2 Determination of Plasmodium species by microscopy examination and molecular diagnosis

\begin{tabular}{|c|c|c|c|c|c|c|c|}
\hline \multirow[t]{2}{*}{ Microcopic } & \multicolumn{2}{|c|}{ Parasitaemia (No. of parasites/ $\mu \mathrm{l}$ ) } & \multirow[b]{2}{*}{ No. } & \multicolumn{2}{|c|}{ Nested PCR } & \multicolumn{2}{|c|}{ Real-time PCR } \\
\hline & Species & Intensity (parasite/ul) & & Species & No. & Species & No. \\
\hline \multirow[t]{13}{*}{ Microcopy positive } & P. falciparum & Very Low $(\leq 100)$ & 7 & Pf & 6 & Pf & 5 \\
\hline & & Low (101-500) & 26 & Pf & 25 & Pf & 21 \\
\hline & & Low-middle (501-3000) & 33 & Pf & 32 & Pf & 32 \\
\hline & & Middle $(3001-10,000)$ & 30 & Pf & 30 & Pf & 30 \\
\hline & & Middle-high $(10,001-100,000)$ & 96 & Pf & 96 & Pf & 96 \\
\hline & & High $(>100,000)$ & 50 & Pf & 50 & Pf & 50 \\
\hline & & Error correction (3000) & 1 & $\mathrm{Pf}+\mathrm{Po}$ & 1 & $\mathrm{Pf}+\mathrm{Po}$ & 1 \\
\hline & P. vivax & From 100 to 10,000 & 15 & $\mathrm{PV}$ & 15 & $\mathrm{PV}$ & 15 \\
\hline & & Error correction & 2 & $P v+P o$ & 2 & $P v+P o$ & 2 \\
\hline & P. ovale & From 100 to 10,000 & 19 & Po & 19 & Po & 21 \\
\hline & & Error correction & 2 & $P f^{a}+P o$ & 2 & $\mathrm{Pf}+\mathrm{Po}$ & 0 \\
\hline & P. malariae & From 100 to 10,000 & 6 & $\mathrm{Pm}$ & 6 & $\mathrm{Pm}$ & 6 \\
\hline & P. falciparum + P. ovale & 50,000 & 1 & Po & 1 & Po & 1 \\
\hline \multirow[t]{2}{*}{ Microcopy negative } & P. falciparum ${ }^{\mathrm{b}}$ & & 7 & Pf & 5 & Pf & 3 \\
\hline & Suspected case & & 1 & Pf & 1 & Pf & 1 \\
\hline Total & & & 296 & & 291 & & 284 \\
\hline
\end{tabular}

a The nested PCR products of these cases have been confirmed by DNA sequencing. ${ }^{\mathrm{b}}$ These cases were RDT positive for Pf

Table 3 Comparison analysis of diagnostic tools for imported Plasmodium species infection in Wuhan, China

\begin{tabular}{|c|c|c|c|c|c|c|c|c|}
\hline \multirow[b]{2}{*}{ Species } & \multicolumn{8}{|l|}{ Nested PCR } \\
\hline & P. falciparum & P. vivax & P. ovale & P. malariae & $\begin{array}{l}P . \\
\text { falciparum }+P . \\
\text { ovale }\end{array}$ & P. vivax $+P$. ovale & Negative & Total (\%) \\
\hline \multicolumn{9}{|l|}{ Microscopy } \\
\hline P. falciparum & 239 & 0 & 0 & 0 & 1 & 0 & 3 & $243(82.09)$ \\
\hline P. vivax & 0 & 15 & 0 & 0 & 0 & 2 & 0 & $17(5.74)$ \\
\hline P.ovale & 0 & 0 & 19 & 0 & 2 & 0 & 0 & $21(7.09)$ \\
\hline P. malariae & 0 & 0 & 0 & 6 & 0 & 0 & 0 & $6(2.03)$ \\
\hline P. falciparum + P. ovale & 0 & 0 & 1 & 0 & 0 & 0 & 0 & $1(0.34)$ \\
\hline Negative $^{\mathrm{a}}$ & 6 & 0 & 0 & 0 & 0 & 0 & 2 & $8(2.70)$ \\
\hline Total (\%) & $245(82.77)$ & $15(5.07)$ & $20(6.76)$ & $6(2.03)$ & $3(1.01)$ & $2(0.68)$ & $5(1.69)$ & $296(100.00)$ \\
\hline \multicolumn{9}{|l|}{ Real-time PCR } \\
\hline P. falciparum & 238 & 0 & 0 & 0 & 0 & 0 & 0 & $238(80.41)$ \\
\hline P. vivax & 0 & 15 & 0 & 0 & 0 & 0 & 0 & $15(5.07)$ \\
\hline P.ovale & 0 & 0 & 20 & 0 & 2 & 0 & 0 & $22(7.43)$ \\
\hline P. malariae & 0 & 0 & 0 & 6 & 0 & 0 & 0 & $6(2.03)$ \\
\hline P. falciparum +P. ovale & 0 & 0 & 0 & 0 & 1 & 0 & 0 & $1(0.34)$ \\
\hline P. vivax + P. ovale & 0 & 0 & 0 & 0 & 0 & 2 & 0 & $2(0.68)$ \\
\hline Negative & 7 & 0 & 0 & 0 & 0 & 0 & 5 & $12(4.05)$ \\
\hline Total (\%) & $245(82.77)$ & $15(5.07)$ & $20(6.76)$ & $6(2.03)$ & $3(1.01)$ & $2(0.68)$ & $5(1.69)$ & $296(100.00)$ \\
\hline
\end{tabular}

a These included 7 RDT positive and 1 RDT negative but suspected cases

as the following performance assessment of the diagnostic methods. As shown in Table 4, for microscopy, the sensitivities of identification of $P$. falciparum, $P$. vivax, P. ovale and P. malariae were $96.77 \%, 100 \%, 88.00 \%$ and
$100.00 \%$, respectively. Specificities for P. falciparum diagnosis were $91.67 \%$ and $100.00 \%$ for the other three species. The probabilities of identification of $P$. falciparum, $P$. vivax, $P$. ovale and $P$. malariae by microscopy from 
Table 4 Performance of microscopy and real-time PCR compared to the reference nested PCR, including sensitivity, specificity, positive predictive value (PPV), negative predictive value (NPV), and disease prevalence (DP)

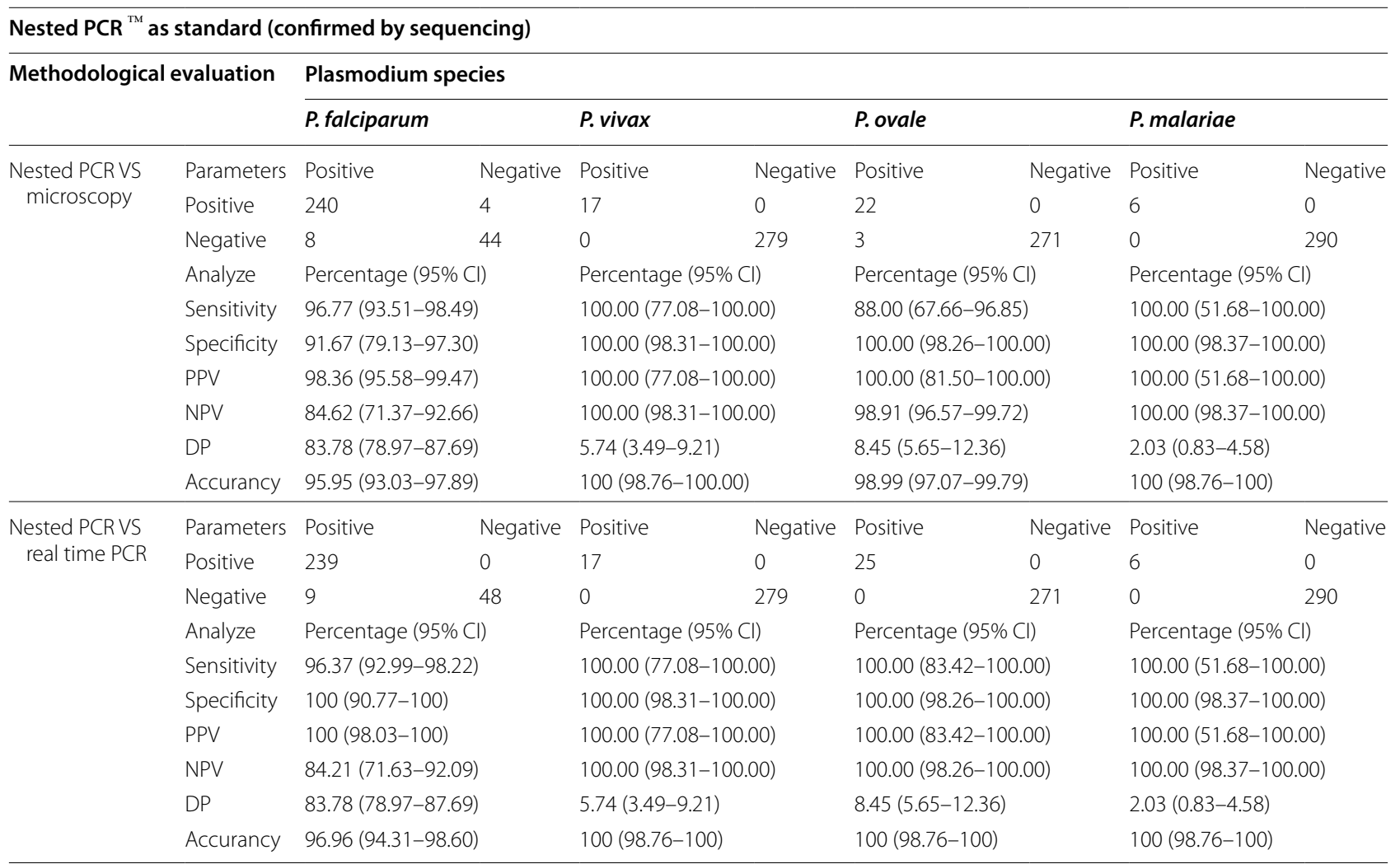

the predicted positive (PPV) and not identification from the predictive negative (NPV) samples were $98.36 \%$ and 84.62\% (P. falciparum), $100.00 \%$ and $100.00 \%$ (P. vivax), $100.00 \%$ and $98.91 \%$ (P. ovale), $100.00 \%$ and $100.00 \%$ ( $P$. malariae), respectively. For the detection of $P$. falciparum by real-time PCR, sensitivity, specificity, PPV and NPV were $96.37 \%, 100 \%, 100 \%$ and $84.21 \%$, respectively. These four assessment indexes were all $100 \%$ for the other three species diagnosed by real-time PCR.

The results also revealed that $P$. falciparum (83.78\%) infection was the most prevalent, followed by $P$. ovale (8.45\%), P. vivax (5.74\%) and P. malariae (2.03\%) among the imported malaria cases in Wuhan, China. Since RDT could only distinguish falciparum and non-falciparum Plasmodium species infection, RDT was not involved in the methodological evaluation of these samples.

\section{Origin and years distribution of the patients}

Tracing the origin of the imported malaria patients demonstrated the patients returned from 28 countries of Africa and 4 countries of Asia (Fig. 3a). Of the total 291 patients confirmed by nested PCR, 112 (38.49\%) malaria patients were infected in West Africa, followed by Central Africa (66 cases, 22.68\%), Southern Africa (62 cases,
21.31\%), East Africa (38 cases, 13.06\%), SE Asia (9 cases, $3.09 \%$ ) and South Asia (4 cases, 1.37\%) (Fig. 3b). The distribution of malaria patients caused by $P$. falciparum was in strong accordance with above general tendency, including 102 cases from West Africa, 55 from Central Africa, 55 from Southern Africa, 27 from East Africa and 6 from SE Asia. Amongst the P. vivax patients, 8 returned from East Africa. The remainders all returned from SE Asia (3 cases) and South Asia (4 cases), respectively. The $P$. ovale patients returned from West Africa $(10 / 20)$, Central Africa (8/20) and Southern Africa (2/20). Only 6 P. malariae infected patients were involved, and three returned from Southern Africa, two from Central Africa and one from East Africa. The five mixed infection patients also returned from the same three regions as the P. malariae infection group.

From 2011 to 2016 (Fig. 3b), the number of imported malaria patients has obviously increased yearly ( $\mathrm{F}=15.11, \quad \mathrm{P}=0.018)$. Luckily, only 20 imported malaria patients were reported by the CDC and hospitals of Wuhan in 2017. However, the number of clinical malaria patients in 2018 increased to 44 cases. It is interesting to note that the predominant species was $P$. 


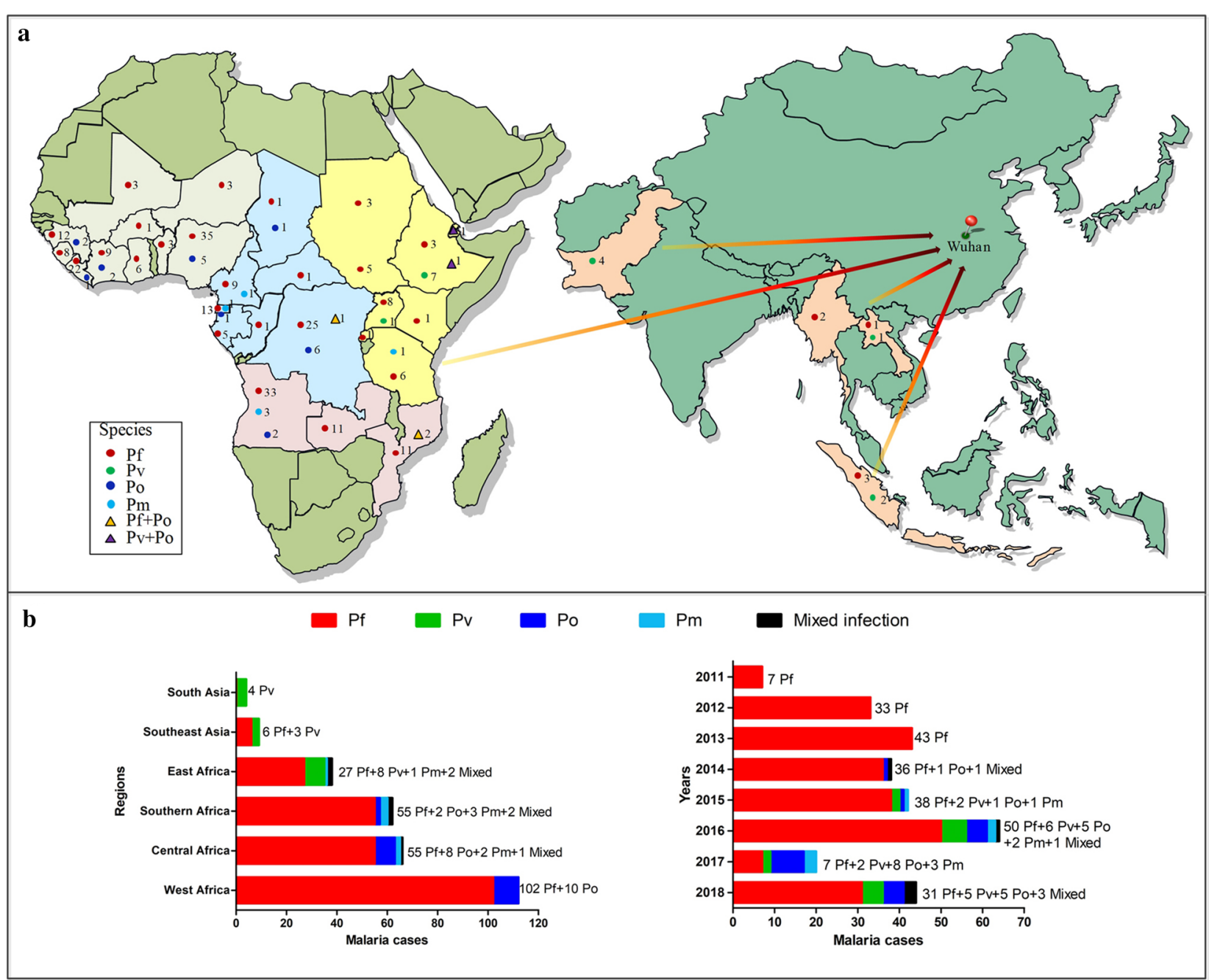

Fig. 3 The importation origin and year distribution of imported malaria cases in Wuhan, China, from 2011 to 2018. a The map of import ation origin and cases numbers for the four Plasmodium species by country. $\mathbf{b}$ The number counting of patients infected with each Plasmodium species by four importation regions in Africa, two in Asia and years

falciparum throughout the surveyed period. However, it is worth mentioning no consistent increasing trends in the prevalence of $P$. falciparum parasites infection $(\mathrm{F}=0.078, \mathrm{P}=0.790)$ was detected yearly. Other Plasmodium species, including $P$. vivax, $P$. ovale and $P$. malariae single infection or mixed infection, were not identified until 2014. In the next 5 years (2014-2018), patients infected with $P$. vivax (15 cases), P. ovale (20 cases), $P$. malariae (6 cases) and mixed parasite species (5 cases) were seen. In this period (2014-2018), the total imported non-falciparum cases showed no increasing trend in prevalence by year $(\mathrm{F}=4.765$, $\mathrm{P}=0.117)$. Neither $P$. vivax $(\mathrm{F}=0.217, \mathrm{P}=0.687)$ nor
P. ovale $(\mathrm{F}=5.000, \mathrm{P}=0.111)$ significantly increased by year.

\section{Discussion}

In 2020, China hopes that national malaria elimination will become a real possibility based on effective control measures [4]. Although no indigenous malaria case has been reported in China since 2017, imported malaria is becoming a serious obstacle to malaria elimination. If China plans to achieve the stated goals on schedule, continuous surveillance of imported malaria is an essential measure. As an important city in Central China, Wuhan has a population of 11.08 million. It also faces similar problems: imported malaria cases increased annually 
accompanied by the disappearance of indigenous malaria cases since 2013 [5]. Thus, it is necessary to monitor the epidemic status of imported malaria in China, including in Wuhan. Furthermore, identification of the malaria parasite species with timely and effective methods could provide valuable information for developing suitable clinical treatment.

In the current study, several discrepant results were obtained by the four different diagnostic methods, which ultimately revised 5 cases from single to mixed infection and 6 cases from negative to positive. The confirmed data revealed that $95.5 \%$ of the imported malaria patients had returned from Africa, and P. falciparum was the dominant imported species. Analysis of the performance of the diagnostic methods involved also revealed some limitations in their usage. Of the 243 P. falciparum cases identified by microscopy, one case later proved to be infected with $P$. falciparum plus $P$. ovale by both molecular tests. Two microscopy-positive $P$. vivax cases were also found to be cases of $P$. vivax plus $P$. ovale. Likewise, two patients with single $P$. ovale infection by microscopy were proven as $P$. ovale plus $P$. falciparum infection by nested PCR. In previous studies, $P$. ovale was also frequently reported to be involved in mixed infection with other Plasmodium species [20, 46, 47]. These results demonstrate the limitations of microscopy in the identification of mixed infection and the highly specialized requirements of the trained observers [48]. The identification of $P$. o. curtisi and $P$. o. wallikeri in 20 single $P$. ovale infection cases, which were unable to be distinguished by microscopy, also highlighted the advantages of molecular tools in species identification. Their diagnosis will offer a clue for the precise treatment of malaria patients. Subsequently, nested PCR also proved 6 cases as P. falciparum infection, which included 5 microscopy-negative but RDTpositive cases and one double-negative case. This was probably because the level of parasitaemia was too low to be observed in these cases. As reported in previous studies $[49,50]$, microscopy has a level of detection about 50-500 parasites/ $\mu$ l for Plasmodium, but the threshold, 50 parasites $/ \mu \mathrm{l}$, is rarely noticeable unless under optimum conditions. This means that it is quite difficult for observers to accurately identify the species with relatively low parasitaemia, especially in mixed infections.

In the analysis of sensitivity, specificity, PPV and NPV, nested PCR-based detection was chosen as the reference standard. Actually, nested PCR is commonly selected as a reference method [51, 52]. By comparing to nested PCR, microscopy (96.77\%) showed similar sensitivity to real-time PCR $(96.37 \%)$ for P. falciparum identification. However, the specificity of microscopy was only $91.67 \%$, lower than the $100 \%$ of rea1-time PCR detection. By designing complementary probes to target gene sequences, the Taqman probe is another guarantee besides the primers to enhance the specificity and avoid false-positive results [38]. The NPV for $P$. falciparum detection was approximately $85 \%$ in both microscopy and real-time PCR detection, indicating a relatively high false-negative rate of approximately $15 \%$ for these two methods. A false-negative rate as high as $19.4 \%$ for microscopy was reported in a previous study [53]. In another study, NPV was as low as $65.8 \%$ for microscopy detection [54]. These indicated the persistent limitations and instability of microscopy diagnosis. For real-time PCR in the present study, its high false-negative rate was mainly attributed to its failure to diagnose 9 P. falciparum cases consisting of $7 \mathrm{sam}$ ples with low parasite density $(0-500$ parasites/ $\mu \mathrm{l})$ and 2 mixed infection samples. In a previous study, the same real-time PCR primers and probes were assessed [55]. Although only 198 of 207 (95.7\%) malaria samples were accurately diagnosed at the species level, the NPV for $P$. falciparum detection was $100 \%$. This indicated that diagnostic performance may vary with the reaction conditions, including the DNA quality, reaction system and even the performance of the laboratory technicians, remaining us of the significance for optimization of the reaction system. For $P$. ovale, the sensitivity $(88.00 \%)$ of microscopic identification was relatively low, and the NPV for P. ovale was $98.91 \%$. Two of the $3 P$. ovale cases that failed to be detected by microscopy were proved to be $P$. ovale plus $P$. vivax mixed infections. This may be due to the similar morphology between P. ovale and P. vivax [12]; as a result, the species with a relatively lower parasitaemia level may be hidden. The four indexes (Table 4) in real-time PCR detection were all $100 \%$ for $P$. vivax, $P$. malariae and $P$. ovale detection, revealing the high consistency between the two molecular tools in the identification of these three species. Plasmodium malariae could be accurately diagnosed by all three methods. This may be because only $6 P$. malariae cases were involved in the study. The primers for real-time PCR used in this study have been used in several previous studies $[35,56]$. However, it has been reported that simultaneous amplification of different templates was difficult and that the primers preferred to amplify species with higher parasitaemia as a result of competition for the shared primers (Plasmo1 and Plasmo2). In the present data, 7 cases out of the total 9 nested PCR-positive patients failed to be identified by real-time PCR. Actually, all had low parasitaemia and the other two had mixed infections. Similar phenomena were also reported in previous studies [57, 58]. A false negative result means a person with Plasmodium infection failed to be diagnosed. This could cause a misdiagnosis, delayed treatment of 
malaria and even lead to a life-threatening problem, especially for $P$. falciparum infection. Beyond the individual consequences, false-negative patients may also spread malaria and produce resistance to anti-malarial drugs if given incorrect treatment due to the lack of an exact diagnosis [53].

Although nested PCR showed the highest sensitivity and real-time PCR had the best specificity, the role of microscopy and RDT is not controversial. Use of the two molecular methods relies on DNA extraction from blood samples. If errors happen during the extraction, a false-negative would probably occur. For example, in a previous study, 10 malaria cases failed to be identified by molecular methods due to problems with the nucleic acid extraction, and the reasons were only identified after repeated experiments [59]. Therefore, the combined use of the four methods is quite necessary and highly recommended if conditions permit. Both microscopy and RDT can offer a preliminary result and suggest further diagnostic directions. Based on this valuable information, the Plasmodium species can then be confirmed by molecular methods, including nested PCR and real-time PCR.

The origin of infection of the patients was consistent with a previous report referring to the epidemiologic features of imported malaria in China [60]. In the epidemic regions of Africa and SE Asia, the natural environment, healthcare and situation of economic development may have primary influences on malaria infection. Chinese people overseas, especially those that do not live for long periods in epidemic areas, usually lack adaptive immunity and related awareness of local Plasmodium infection [60]. Additionally, there are frequently asymptomatic patients [61]. Workers returned from these areas, particularly West Africa, Central Africa, and Southern Africa, should be encouraged to undergo malaria testing. As the dominant malaria species, the prevalence and origins of $P$. falciparum were similar to other studies [53, 62]. Therefore, prevention and treatment against $P$. falciparum should be highly considered in Wuhan. Over the years (from 2014 to 2018), the Plasmodium species leading to imported malaria were becoming diversified, just as in other provinces of China, including Shandong [59], Zhejiang [62], Shanxi [63] and Chongqing municipality [64]. In this period, the imported non-falciparum cases and $P$. vivax/P. ovale cases showed no significantly increasing trend by year, but more attention should be focused on this increasing Plasmodium species diversity. The increase in imported $P$. vivax and $P$. ovale cases may cause the re-introduction of malaria into regions without cases $[65,66]$. Plasmodium malariae can survive in humans for many years and keep infectivity of its vector at a truly low parasitaemia load [67]. The sharp decrease in imported malaria cases in 2017 may be a good sign, indicating the successful performance of malaria control. However, the cases increased again in 2018, warning us about the challenges of complete elimination of Plasmodium infection worldwide, even in China.

Additionally, results in the present study showed no significant seasonal correlation $(\mathrm{P}=0.759)$ by the Pearson correlation analysis among the imported malaria cases during the study period. One small peak of the seasonal index [68] appeared in May (1.44) to June (1.32). Another study of malaria in Hubei province from 2005 to 2016 revealed that indigenous malaria had an obvious seasonal fluctuation during their study period, with a peak of seasonal index in August (2.26). However, only three small peaks of seasonal index (all approximately 1.3) for imported cases were found, including one in January, a second one in May and the last one in September [5]. This indicated that there are differences in the incidence of monthly cases between indigenous and imported malaria. Comparisons with five neighbouring provinces/cities of Hubei also showed that no obvious correlation existed between season and imported malaria cases in these regions [64, 69-72]. Even so, two time slots should be paid more attention for the prevention of imported malaria. One is the Chinese Spring Festival, which leads to the most frequent migration between provinces in China and brings many overseas Chinese home [5, 63, 64, 71]. Another is the anopheles active phase [5, 64, 70-72]. Importantly, commuting and the movement of imported malaria cases between provinces should also be of concern, which has been reported in another city of China [71].

Indeed, besides an early and precise diagnosis for proper treatment, some preventative measures should also be emphasized from two major aspects before people leave for an epidemic area: (1) Prevention of mosquito bites. Travellers could protect themselves by using insect repellents, insecticide-treated nets, aerosol sprays and protective clothing. (2) Proper usage of chemoprophylactic anti-malarial drugs. Anti-malarial prophylactic regimens may not provide complete protection, but proper chemoprophylaxis could significantly lower the risk of fatal malaria. According to the prevalence of Plasmodium species at the destination and the conditions of the travellers (healthy adults, children, pregnant women or immunosuppressed travellers), different chemoprophylactic schedules should be advised by the local government according to the guide on international travel and health published by the WHO. Only a combination of prevention and treatment can lead to the achievement of the goal of malaria elimination around the world. 


\section{Conclusions}

The efficiency of $18 \mathrm{~S}$ ssrRNA-based nested PCR and real-time PCR in the differentiation of four Plasmodium species and two subspecies of $P$. ovale was assessed. The results highlighted, once again, that PCR-based methods are irreplaceable for exact species determination of imported malaria cases, especially for mixed infections. Therefore, the combined use of the four methods should be emphasized, if conditions permit. These data are a very important epidemiological resource and could supply guidance for the surveillance, prevention and timely treatment of imported malaria in Wuhan, China. The guiding effect is also significant for epidemic areas, as shown in the origin distribution survey, and for countries at potential high risk of importing malaria worldwide.

\section{Abbreviations}

RDT: Rapid diagnosis test; PPV: Positive Predictive value; NPV: Negative Predictive value; DP: Disease prevalence; CDC: Center for Disease Prevention and control.

\section{Acknowledgements}

The authors thank all the participants who contributed their blood samples, laboratory technicians, clinician, nurses, and everyone who supported this study directly or indirectly.

\section{Authors' contributions}

$J \mathrm{~L}$ and $\mathrm{KW}$ conceived the study, and participated in its design and coordination. KW, MXX, and YY carried out sample collection. YTX and JL interpreted the data and wrote the manuscript. YTX, TTJ and YY carried out molecular assays and performed statistical analysis. YTX, TTJ, KW and HBT participated in molecular assays and data analysis. YTX and $J$ reviewed the final manuscript. All authors read and approved the final manuscript.

\section{Funding}

This study was supported by the National Natural Science Foundation of China (J.L. Grant Number 81802046), Foundation for Innovative Research Team of Hubei University of Medicine (J.L. Grant Number FDFR201603), and Health Commission of Hubei Province Scientific Research Project (YT.X. Grant Number WJ2019Q012). The funders had no role in study design, data collection and analysis, decision to publish, or preparation of the manuscript.

\section{Availability of data and materials}

The datasets analysed in this study are available from the corresponding author on reasonable request.

\section{Ethics approval and consent to participate}

Current study was approved by the Medical Ethics Committees of the Hubei University of Medicine and Wuhan City Center for Disease Prevention and Control. The written informed consent was obtained from all participated individuals.

\section{Consent for publication}

Not applicable.

\section{Competing interests}

The authors declare that they have no competing interests.

\section{Author details}

${ }^{1}$ Department of Human Parasitology, School of Basic Medical Sciences, Hubei University of Medicine, Shiyan 442000, People's Republic of China. ${ }^{2}$ Department of Infectious Diseases, Renmin Hospital, Hubei University of Medicine, Shiyan 442000, People's Republic of China. ${ }^{3}$ Department of Schistosomiasis and Endemic Diseases, Wuhan City Center for Disease Prevention and Control, Wuhan 430015, People's Republic of China.

Received: 16 January 2020 Accepted: 25 August 2020

Published online: 03 September 2020

\section{References}

1. WHO. World malaria report 2019. Geneva: World Health Organization; 2019.

2. WHO. Global technical strategy for malaria 2016-2030. Geneva: World Health Organization; 2015.

3. Xia ZG, Wang RB, Wang DQ, Feng J, Zheng Q, Deng CS, et al. China-Africa cooperation initiatives in malaria control and elimination. Adv Parasitol. 2014;86:319-37.

4. Feng J, Zhang L, Huang F, Yin JH, Tu H, Xia ZG, et al. Ready for malaria elimination: zero indigenous case reported in the People's Republic of China. Malar J. 2018;17:315.

5. Xia J, Huang X, Sun L, Zhu H, Lin W, Dong X, et al. Epidemiological characteristics of malaria from control to elimination in Hubei Province, China, 2005-2016. Malar J. 2018;17:81.

6. Phillips RS. Current status of malaria and potential for control. Clin Microbiol Rev. 2001;14:208-26.

7. Phillips MA, Burrows JN, Manyando C, van Huijsduijnen RH, Van Voorhis WC, Wells TNC. Malaria. Nat Rev Dis Primers. 2017;3:17050.

8. WHO. International Travel and Health—Chapt. 7: Malaria. Geneva: World Health Organization, 2020. https://www.who.int/ith/2017-ith-chapter7. pdf?ua $=1 \& u a=1$. Accessed 5 May 2020.

9. Mueller I, Galinski MR, Baird JK, Carlton JM, Kochar DK, Alonso PL, et al. Key gaps in the knowledge of Plasmodium vivax, a neglected human malaria parasite. Lancet Infect Dis. 2009;9:555-66.

10. Gething PW, Elyazar IR, Moyes CL, Smith DL, Battle KE, Guerra CA, et al. A long neglected world malaria map: plasmodium vivax endemicity in 2010. PLoS Negl Trop Dis. 2012;6:e1814.

11. de Laval F, Simon F, Bogreau H, Rapp C, Wurtz N, Oliver M, et al. Emergence of Plasmodium ovale malaria among the French Armed Forces in the Republic of Ivory Coast: 20 years of clinical and biological experience. Clin Infect Dis. 2014;58:e122-8.

12. Miller RH, Obuya CO, Wanja EW, Ogutu B, Waitumbi J, Luckhart S, et al. Characterization of Plasmodium ovale curtisi and P. ovale wallikeri in Western Kenya utilizing a novel species-specific real-time PCR assay. PLoS Negl Trop Dis. 2015;9:e0003469.

13. Sutherland CJ, Tanomsing N, Nolder D, Oguike M, Jennison C, Pukrittayakamee $S$, et al. Two nonrecombining sympatric forms of the human malaria parasite Plasmodium ovale occur globally. J Infect Dis. 2010;201:1544-50.

14. Nolder D, Oguike MC, Maxwell-Scott H, Niyazi HA, Smith V, Chiodini PL, et al. An observational study of malaria in British travellers: Plasmodium ovale wallikeri and Plasmodium ovale curtisi differ significantly in the duration of latency. BMJ Open. 2013;3:e002711.

15. Zhou R, Li S, Zhao Y, Yang C, Liu Y, Qian D, et al. Characterization of Plasmodium ovale spp. imported from Africa to Henan Province. China. Sci Rep. 2019;9:2191.

16. Cox-Singh J. Zoonotic malaria: Plasmodium knowlesi, an emerging pathogen. Curr Opin Infect Dis. 2012;25:530-6.

17. Cox-Singh J, Davis TM, Lee KS, Shamsul SS, Matusop A, Ratnam S, et al. Plasmodium knowlesi malaria in humans is widely distributed and potentially life threatening. Clin Infect Dis. 2008;46:165-71.

18. Singh B, Kim Sung L, Matusop A, Radhakrishnan A, Shamsul SS, Cox-Singh $J$, et al. A large focus of naturally acquired Plasmodium knowlesi infections in human beings. Lancet. 2004;363:1017-24.

19. Zimmerman PA, Mehlotra RK, Kasehagen LJ, Kazura JW. Why do we need to know more about mixed Plasmodium species infections in humans? Trends Parasitol. 2004;20:440-7.

20. Mueller I, Zimmerman PA, Reeder JC. Plasmodium malariae and Plasmodium ovale-the "bashful" malaria parasites. Trends Parasitol. 2007:23:278-83.

21. Baird JK. Evidence and implications of mortality associated with acute Plasmodium vivax malaria. Clin Microbiol Rev. 2013;26:36-57. 
22. Bichara C, Flahaut P, Costa D, Bienvenu AL, Picot S, Gargala G. Cryptic Plasmodium ovale concurrent with mixed Plasmodium falciparum and Plasmodium malariae infection in two children from Central African Republic. Malar J. 2017;16:339.

23. Kyabayinze DJ, Tibenderana JK, Odong GW, Rwakimari JB, Counihan H. Operational accuracy and comparative persistent antigenicity of HRP2 rapid diagnostic tests for Plasmodium falciparum malaria in a hyperendemic region of Uganda. Malar J. 2008;7:221.

24. Chanie M, Erko B, Animut A, Legesse M. Performance of CareStart ${ }^{\mathrm{TM}}$ malaria Pf/Pv combo test for the diagnosis of Plasmodium falciparum and Plasmodium vivax infections in the afar region, North East Ethiopia. Ethiopian J Health Dev. 2011;25:206-11.

25. Payne D. Use and limitations of light microscopy for diagnosing malaria at the primary health care level. Bull World Health Organ. 1988;66:621-6.

26. Ohrt C, Sutamihardja MA, Tang D, Kain KC. Impact of microscopy error on estimates of protective efficacy in malaria-prevention trials. J Infect Dis. 2002;186:540-6.

27. Hanscheid T. Current strategies to avoid misdiagnosis of malaria. Clin Microbiol Infect. 2003;9:497-504.

28. Dhiman S, Goswami D, Kumar D, Rabha B, Sharma DK, Bhola RK, et al. Nested PCR detection of Plasmodium malariae from microscopy confirmed P. falciparum samples in endemic area of NE India. Folia Parasitol (Praha). 2013;60:401-5.

29. Krishna S, Bharti PK, Chandel HS, Ahmad A, Kumar R, Singh PP, et al. Detection of mixed infections with Plasmodium spp. by PCR, India, 2014 Emerg Infect Dis. 2015;21:1853-7.

30. Lau YL, Lai MY, Anthony CN, Chang PY, Palaeya V, Fong MY, et al. Comparison of three molecular methods for the detection and speciation of five human Plasmodium species. Am J Trop Med Hyg. 2015;92:28-33.

31. Dimaio MA, Pereira IT, George TI, Banaei N. Performance of BinaxNOW for diagnosis of malaria in a U.S. hospital. J Clin Microbiol. 2012:50:2877-80.

32. Gamboa D, Ho MF, Bendezu J, Torres K, Chiodini PL, Barnwell JW, et al. A large proportion of $P$. falciparum isolates in the Amazon region of Peru lack pfhrp2 and pfhrp3: implications for malaria rapid diagnostic tests. PLoS One. 2010;5:e8091.

33. Deme AB, Park DJ, Bei AK, Sarr O, Badiane AS, Gueye Pel H, et al. Analysis of pfhrp2 genetic diversity in Senegal and implications for use of rapid diagnostic tests. Malar J. 2014;13:34.

34. Parr JB, Belson C, Patel JC, Hoffman IF, Kamthunzi P, Martinson F, et al. Estimation of Plasmodium falciparum transmission intensity in Lilongwe, Malawi, by microscopy, rapid diagnostic testing, and nucleic acid detection. Am J Trop Med Hyg. 2016;95:373-7.

35. Rougemont M, Van Saanen M, Sahli R, Hinrikson HP, Bille J, Jaton K. Detection of four Plasmodium species in blood from humans by $18 \mathrm{~S}$ rRNA gene subunit-based and species-specific real-time PCR assays. J Clin Microbiol. 2004:42:5636-43.

36. Wang B, Han SS, Cho C, Han JH, Cheng Y, Lee SK, et al. Comparison of microscopy, nested-PCR, and Real-Time-PCR assays using high-throughput screening of pooled samples for diagnosis of malaria in asymptomatic carriers from areas of endemicity in Myanmar. J Clin Microbiol. 2014:52:1838-45.

37. Price RN, Uhlemann AC, Brockman A, McGready R, Ashley E, Phaipun $\mathrm{L}$, et al. Mefloquine resistance in Plasmodium falciparum and increased pfmdr1 gene copy number. Lancet. 2004;364:438-47.

38. Smith CJ, Osborn AM. Advantages and limitations of quantitative PCR (Q-PCR)-based approaches in microbial ecology. FEMS Microbiol Ecol. 2009;67:6-20.

39. Bailey JW, Williams J, Bain BJ, Parker-Williams J, Chiodini PL. Guideline: the laboratory diagnosis of malaria. General haematology task force of the British Committee for standards in haematology. Br J Haematol. 2013;163:573-80.

40. Yao $Y$, Wu K, Xu M, Yang $Y$, Zhang $Y$, Yang $W$, et al. Surveillance of genetic variations associated with antimalarial resistance of Plasmodium falciparum isolates from returned migrant workers in Wuhan, Central China. Antimicrob Agents Chemother. 2018;62:e02387-17.

41. Wanja EW, Kuya N, Moranga C, Hickman M, Johnson JD, Moseti C, et al. Field evaluation of diagnostic performance of malaria rapid diagnostic tests in western Kenya. Malar J. 2016;15:456.

42. Bauffe F, Desplans J, Fraisier C, Parzy D. Real-time PCR assay for discrimination of Plasmodium ovale curtisi and Plasmodium ovale wallikeri in the Ivory Coast and in the Comoros Islands. Malar J. 2012;11:307.
43. Snounou G, Singh B. Nested PCR analysis of Plasmodium parasites. Methods Mol Med. 2002;72:189-203.

44. Fuehrer HPSMT, Buczolich K, Bloeschl I, Noedl H. Two techniques for simultaneous identification of Plasmodium ovale curtisi and Plasmodium ovale wallikeri by use of the small-subunit rRNA gene. J Clin Microbiol. 2012;50:4100-2.

45. Kim JY, Ji SY, Goo YK, Na BK, Pyo HJ, Lee HN, et al. Comparison of rapid diagnostic tests for the detection of Plasmodium vivax malaria in South Korea. PLoS ONE. 2013;8:e64353.

46. Dinko B, Oguike MC, Larbi JA, Bousema T, Sutherland CJ. Persistent detection of Plasmodium falciparum, P. malariae, P. ovale curtisi and P. ovale wallikeri after ACT treatment of asymptomatic Ghanaian school-children. Int J Parasitol Drugs Drug Resist. 2013;3:45-50.

47. Betson M, Sousa-Figueiredo JC, Atuhaire A, Arinaitwe M, Adriko M, Mwesigwa G, et al. Detection of persistent Plasmodium spp. infections in Ugandan children after artemether-lumefantrine treatment. Parasitology. 2014;141:1880-90.

48. Mekonnen SK, Aseffa A, Medhin G, Berhe N, Velavan TP. Re-evaluation of microscopy confirmed Plasmodium falciparum and Plasmodium vivax malaria by nested PCR detection in southern Ethiopia. Malar J. 2014;13:48.

49. Guerin PJ, Olliaro P, Nosten F, Druilhe P, Laxminarayan R, Binka F, et al. Malaria: current status of control, diagnosis, treatment, and a proposed agenda for research and development. Lancet Infect Dis. 2002;2:564-73.

50. Moody A. Rapid diagnostic tests for malaria parasites. Clin Microbiol Rev. 2002;15:66-78.

51. Bourgeois N, Boutet A, Bousquet PJ, Basset D, Douard-Enault C, Charachon S, et al. Comparison of three real-time PCR methods with blood smears and rapid diagnostic test in Plasmodium sp. infection. Clin Microbiol Infect. 2010;16:1305-11.

52. Sema M, Alemu A, Bayih AG, Getie S, Getnet G, Guelig D, et al. Evaluation of non-instrumented nucleic acid amplification by loop-mediated isothermal amplification (NINA-LAMP) for the diagnosis of malaria in Northwest Ethiopia. Malar J. 2015;14:44.

53. Berzosa P, de Lucio A, Romay-Barja M, Herrador Z, Gonzalez V, Garcia L, et al. Comparison of three diagnostic methods (microscopy, RDT, and $\mathrm{PCR}$ ) for the detection of malaria parasites in representative samples from Equatorial Guinea. Malar J. 2018;17:333.

54. Alemu A, Fuehrer HP, Getnet G, Kassu A, Getie S, Noedl H. Comparison of Giemsa microscopy with nested PCR for the diagnosis of malaria in North Gondar, north-west Ethiopia. Malar J. 2014;13:174.

55. Lee PC, Chong ETJ, Anderios F, Al Lim Y, Chew CH, Chua KH. Molecular detection of human Plasmodium species in Sabah using PlasmoNex ${ }^{\mathrm{TM}}$ multiplex PCR and hydrolysis probes real-time PCR. Malar J. 2015;14:28.

56. Shokoples SE, Ndao M, Kowalewska-Grochowska K, Yanow SK. Multiplexed real-time PCR assay for discrimination of Plasmodium species with improved sensitivity for mixed infections. J Clin Microbiol. 2009:47:975-80.

57. McKenzie FE, Sirichaisinthop J, Miller RS, Gasser RA Jr, Wongsrichanalai C. Dependence of malaria detection and species diagnosis by microscopy on parasite density. Am J Trop Med Hyg. 2003;69:372-6.

58. Nankabirwa J, Zurovac D, Njogu JN, Rwakimari JB, Counihan H, Snow RW, et al. Malaria misdiagnosis in Uganda-implications for policy change. Malar J. 2009:8:66

59. Xu C, Wei QK, Li J, Xiao T, Yin K, Zhao CL, et al. Characteristics of imported malaria and species of Plasmodium involved in Shandong Province, China (2012-2014). Korean J Parasitol. 2016;54:407-14.

60. Li Z, Zhang Q, Zheng C, Zhou S, Sun J, Zhang Z, et al. Epidemiologic features of overseas imported malaria in the People's Republic of China. Malar J. 2016;15:141.

61. Li Z, Yang Y, Xiao N, Zhou S, Lin K, Wang D, et al. Malaria imported from Ghana by returning gold miners, China, 2013. Emerg Infect Dis. 2015:21:864-7.

62. Zhang X, Yao L, Sun J, Pan J, Chen H, Zhang L, et al. Malaria in Southeastern China from 2012 to 2016: analysis of Imported Cases. Am J Trop Med Hyg. 2018;98:1107-12.

63. Wang T, Zhou SS, Feng J, Oo MM, Chen J, Yan CF, et al. Monitoring and evaluation of intervals from onset of fever to diagnosis before "1-3-7" approach in malaria elimination: a retrospective study in Shanxi Province, China from 2013 to 2018. Malar J. 2019;18:235.

64. Fei L, Shuang Z, Yi Y, Wen-Li H, Shan-Shan L. Epidemiological analysis and control strategy discussion for overseas imported malaria cases reported 
in Chongqing City from 2011 to 2015 (in Chinese). Zhongguo Xue Xi Chong Bing Fang Zhi Za Zhi. 2017;29:310-4.

65. Sleigh $A C$, Liu XL, Jackson S, Li P, Shang LY. Resurgence of vivax malaria in Henan Province, China. Bull World Health Organ. 1998;76:265-70.

66. Wang D, Li S, Cheng Z, Xiao N, Cotter C, Hwang J, et al. Transmission risk from imported Plasmodium vivax malaria in the China-Myanmar border region. Emerg Infect Dis. 2015;21:1861-4.

67. Mohapatra PK, Prakash A, Bhattacharyya DR, Goswami BK, Ahmed A, Sarmah B, et al. Detection \& molecular confirmation of a focus of Plasmodium malariae in Arunachal Pradesh, India. Indian J Med Res. 2008;128:52-6.

68. Xiao D, Long Y, Wang S, Wu K, Xu D, Li H, et al. Epidemic distribution and variation of Plasmodium falciparum and Plasmodium vivax malaria in Hainan, China during 1995-2008. Am J Trop Med Hyg. 2012;87:646-54.

69. Chen H, Yao L, Zhang L, Zhang X, Lu Q, Yu K, et al. Malaria in Zhejiang Province, China, from 2005 to 2014. Am J Trop Med Hyg. 2015;93:305-9.
70. Kang-Ming L, Jun L, Shu-Jiao W, Wei-Wei Z, Xiang-Yang F, Hui Y, et al. Epidemic situation and control strategy of malaria in Guangxi Zhuang Autonomous Region from 2011 to 2018 (in Chinese). Zhongguo Xue Xi Chong Bing Fang Zhi Za Zhi. 2019;31:315-8.

71. Xiao F, Shen XJ, Liao Y, Deng PP. Analysis of imported malaria epidemics in Changsha from 2012 to 2017 (in Chinese). J Med Pest Control. 2012;2019(35):290-2.

72. Yu T, Fu Y, Kong X, Liu X, Yan G, Wang Y. Epidemiological characteristics of imported malaria in Shandong Province, China, from 2012 to 2017. Sci Rep. 2020;10:7568.

\section{Publisher's Note}

Springer Nature remains neutral with regard to jurisdictional claims in published maps and institutional affiliations.
Ready to submit your research? Choose BMC and benefit from:

- fast, convenient online submission

- thorough peer review by experienced researchers in your field

- rapid publication on acceptance

- support for research data, including large and complex data types

- gold Open Access which fosters wider collaboration and increased citations

- maximum visibility for your research: over 100M website views per year

At BMC, research is always in progress.

Learn more biomedcentral.com/submissions 